\title{
2 粒径混合砂を用いた大型海浜断面実験と粒径別漂砂量の算出
}

\author{
田中正博* - 井上 亮** - 佐藤壃司 ${ }^{* * *}$ - 磯 部 雅 彦 $* * * *$ \\ 渡辺晃 $* * * * *$. 池野正明****** ・ 清水隆夫*******
}

\section{1. はじめに}

漂砂源近傍の海岸や養浜工が実施された海岸は広い粒 度分布の底質で構成されることが多く，その変形を精度 よく評価するためには，異粒径砂礫で構成される海浜の 変形機構を理解する必要がある。本研究では現地スケー ルでの現象把握を目的として，大型造波水路を用いた海 浜断面実験を実施した。これまでにも山本ら（1998）に よって同種の大型水路実験が行われているが, 粒径分布 の広い砂を使用しているため, 地形変化と分級過程の特 徵を把握するにとどまっている. 本研究では粒径別漂砂 量を精度よく算出するために, 条件をより単純化して, 粒径分布が双峰型の細粗 2 粒径砂を用いた実験を行い, 地形変化と分級過程を定量的に解釈することとした。

\section{2. 実験方法と実験ケース}

幅 $3.4 \mathrm{~m}$, 深さ $6 \mathrm{~m}$, 長さ $205 \mathrm{~m}$ の大型造波水路に中央 粒径 $0.27 \mathrm{~mm}$ の細砂と $0.84 \mathrm{~mm}$ の粗砂を $7: 3$ の割合 で混合した砂で勾配 $1 / 30$ の砂面をつくり,沖側の水深を $4.5 \mathrm{~m}$ として海浜断面変形実験を行った. 图一 1 に混合 砂の粒径加積曲線を示す，入射波は規則波で，堆積性波 浪 $\left(H_{0}=0.34 \mathrm{~m}, T=3.5 \mathrm{~s}\right)$ を 38 時間作用させた後, 整 地せずに侵食性波浪 $\left(H_{0}=1.0 \mathrm{~m}, T=3.5 \mathrm{~s}\right)$ を 20 時間 作用させた（表一1）.

機器による計測は清水ら（1996）にならい，外力・地 形変化・浮遊砂濃度に関して行った。配置は図一2 および 図-3 に示す通りである. 外力は, 容量式波高計 16 台, 電磁流速計 12 台扔よび 3-D 超音波ドップラー流速計 4 台を水路の側壁際固定点および移動台車に設置し，地形 変化に対応するよう十分な頻度で測定した。地形は移動 台車に取り付けた砂面計で水路内 4 測線を計測した。浮 遊砂濃度は, 浮遊砂濃度計, 採水装置各 13 台で計測し,

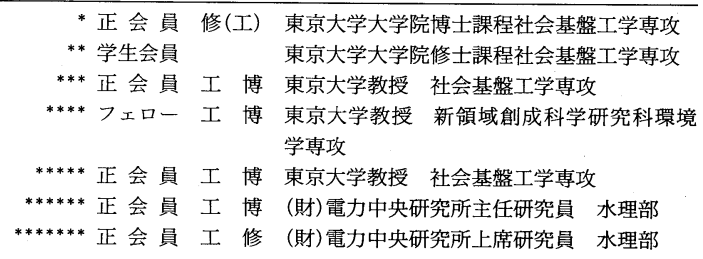

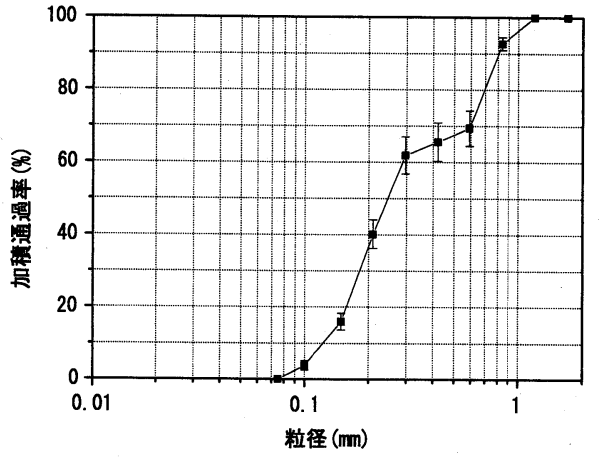

図一1 実験に用いた砂の粒度分布

表一1 実験ケース

\begin{tabular}{c|c|c|c|c|c}
\hline $\begin{array}{c}\text { 実験 } \\
\text { ケース }\end{array}$ & $\begin{array}{c}\text { 波浪 } \\
\text { 件 }\end{array}$ & $\begin{array}{c}\text { 海底 } \\
\text { tan } \beta\end{array}$ & $\begin{array}{c}\text { 換算沖波 } \\
\text { 波高 } \\
H_{0}(\mathrm{~m})\end{array}$ & $\begin{array}{c}\text { 周期 } \\
T(\mathrm{~s})\end{array}$ & $\begin{array}{c}\text { 作用 } \\
\text { 時間 } \\
t(\mathrm{hr})\end{array}$ \\
\hline CASE I & 堆積型 & $1 / 30$ & 0.34 & 3.5 & 38.0 \\
\hline CASE II & 侵食型 & after-1 & 1.00 & 3.5 & 20.0 \\
\hline
\end{tabular}

また遡上計 2 台を配置した。

さらに分級過程を定量的に調べるために, コア試料を 採取して分級の進行状況を測定した。コア試料採取は, 砂面計による砂面高計測の直後に毎回実施し, 図一 3 に 示すように岸沖方向最小 $2.5 \mathrm{~m}$ 間隔で 1 回当たり 25 本 程度採取した。採取方法は, 地盤内に内径 $52 \mathrm{~mm}$ のポリ カーボネイド製中空円筒を専用打込み機で履歴を受けて いない層まで貫入させ，上部に水を充填し栓をした後に 引き抜く方式とした。ささらに砂の移動方向を確認するた めに, 底質の一部を 3 色の着色砂で置換し, その後の移動 状況を追跡した. 採取したコア試料は, 専用押出し機を 用いて表面から $0.5 \sim 10 \mathrm{~cm}$ ごとに切断し, 1 本のコア試 料から平均で 20 個程度の試料を得た. 試料は, 乾燥後, $0.5 \mathrm{~mm}$ のふるいを用いてふるい分けし, 粗砂, 細砂それ ぞれの重量を計測した。

\section{3. 実験結果と考察}

\section{（1）地形変化と分級}

図一 4 および図一5にそれぞれCASEI およびCASE 


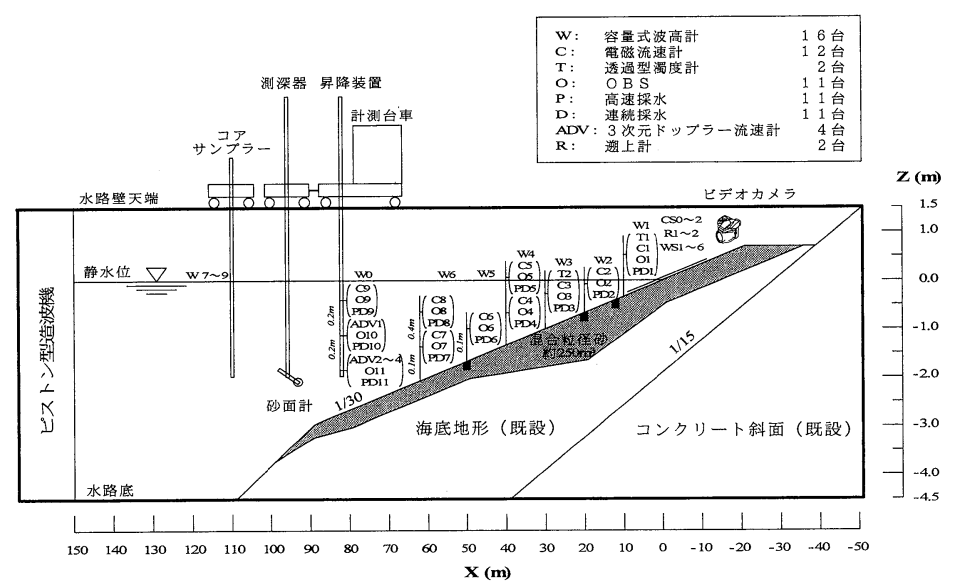

図-2 計測機器の配置

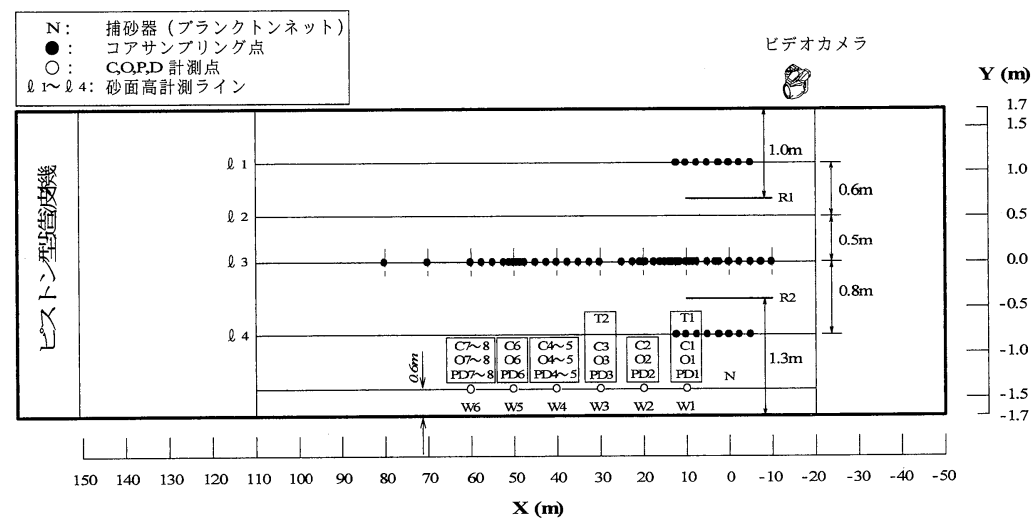

図一3 計測機器の配置およびコア試料採取位置

II の地形変化と分級過程を示す. 両図中 2 本ずつ描画さ れている実線は, 当該時刻および前計測時における砂面 形状である。なお, 砂中の混合率分布は, 隣接する 2 本 のコア試料分析より得られた混合率の鉛直分布を，砂表 面からの深さに応じて岸沖方向の距離で線形補完し求め たものである. CASE I では $X=15 \mathrm{~m}$ 付近に発生した バー (1 h) が, 岸側へ移動するにつれて粗粒化するとと もに (6.6h), 汀線付近のバームに取り込まれる (15h). その後もバームは表面を粗砂に覆われて成長していく (30 h, 38 h). 一方, CASE II では, 沖合に生起したバー ( 3 h) が成長しながら沖側に移動し $(7.2$ h), ある程度 の規模になるとバー頂部の水深を保つようにバーはさら に沖側に移動する（13 h, 20 h). またバーの沖側斜面に は細砂が, 岸側斜面には粗砂が堆積している様子が確認 できる。

\section{（2）波高と戻り流れの分布}

図一6および図一7は，それぞれ図-4および図一5に 対応する地形を計測した後, 波作用再開直後の波高およ
び平均流速の計測結果である. CASE I では, バーの岸向 き移動に伴って砕波点も岸向きに移動するが，その後 バームの成長とともに再び砕波点は沖に移動している. また砕波帯内に打ける戻り流れの流速は $10 \mathrm{~cm} / \mathrm{s}$ 程度 以下であった。一方 CASE II では，砕波点はバーの沖向 き移動に対応してほぼ単調に沖向きに移動している。戻 り流れ流速の分布はバーの成長度合いで変化する.即ち, バーが未発達の $3.2 \mathrm{~h}$ までの時間では, $20 \mathrm{~cm} / \mathrm{s}$ 程度の 戻り流れが汀線極く近傍を除く砕波帯全域で発達してい る.これに対し, バーが発達した $7.2 \mathrm{~h}$ 以後では, 砕波点 直ぐ岸側のトラフの部分で $50 \mathrm{~cm} / \mathrm{s}$ を越える極めて強 い戻り流れが発達するものの, その他の領域では, 戻り 流れがほとんど発達しない.これは, バーの発達により, 砕波形式が強い巻き波型砕波に変化したためと考えら れ，これに応じて波高の岸沖分布も変化し，バー直後で 急激な波高減衰が生じるようになっている。

なお， $7.25 \mathrm{~h}$ および $19.9 \mathrm{~h}$ の $X=60 \mathrm{~m}$ で波高が低く なっているが, これはバーによる反射波の影響であると 


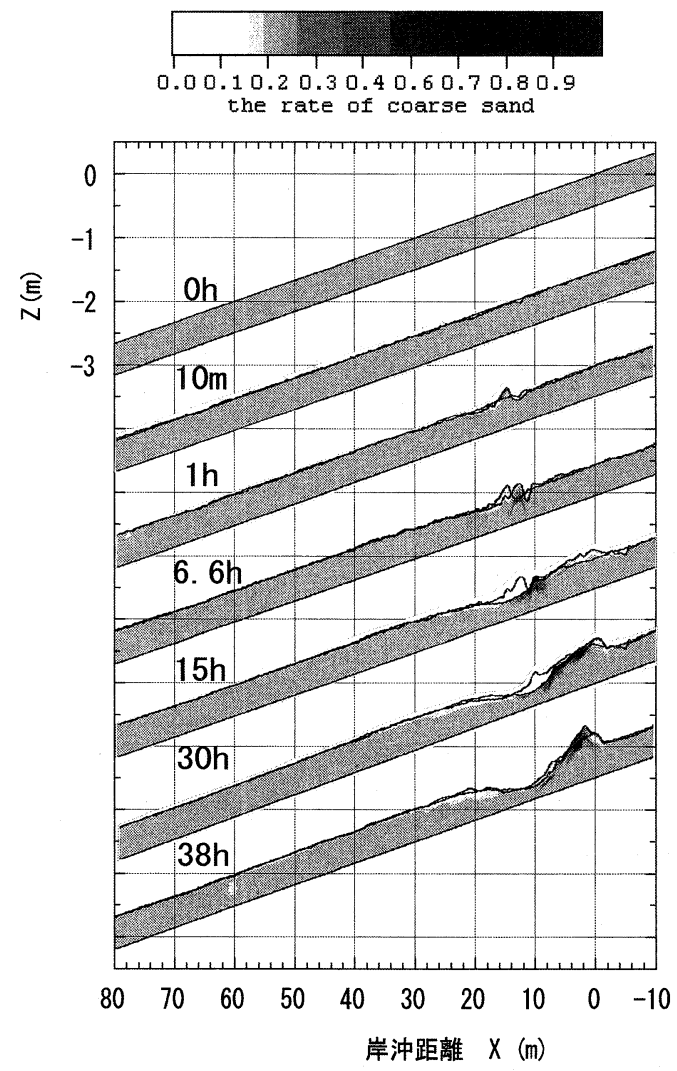

図一４地形変化と粗砂混合率の分布（CASE I ：堆積性）

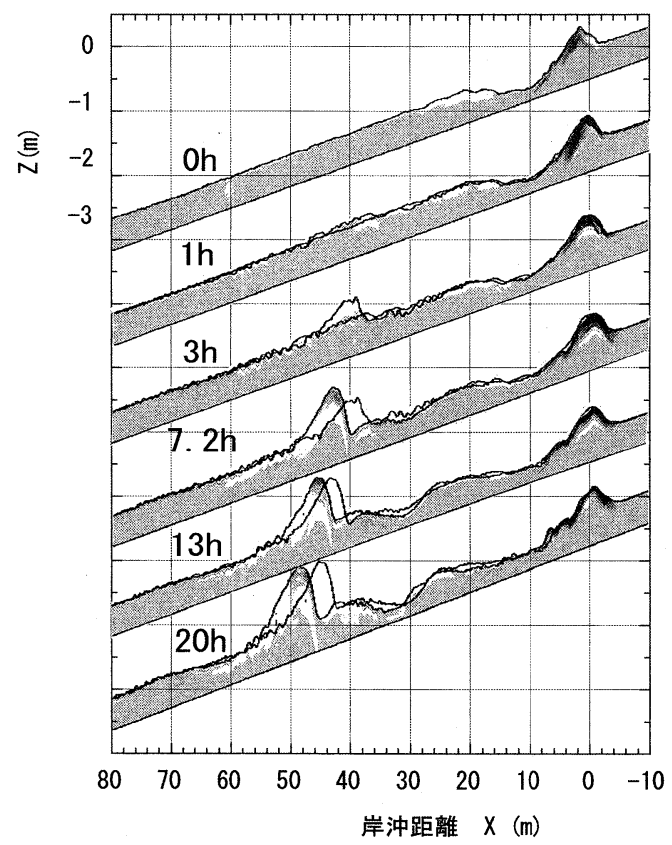

図一5 地形変化と粗砂混合率の分布（CASE II：侵食性）

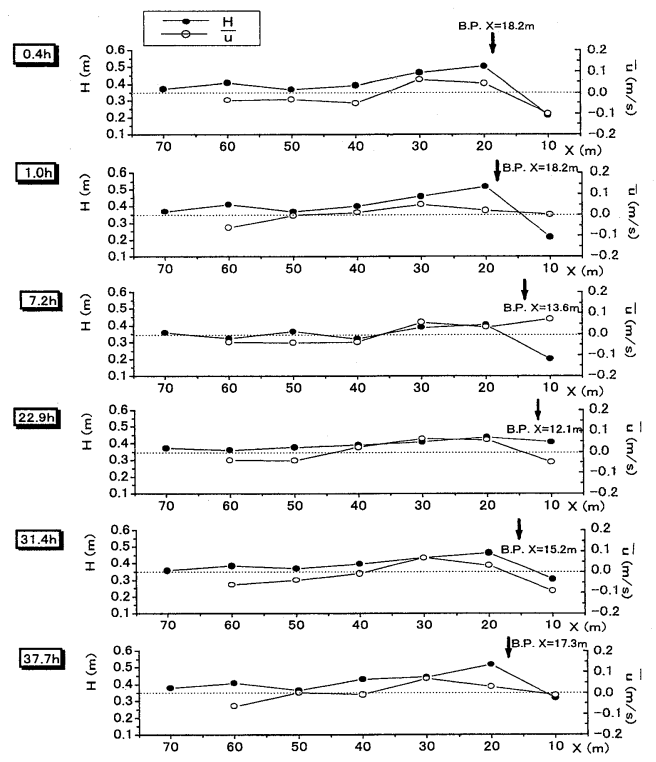

図一6 波高・戻り流れの変化（CASE I：堆積性）

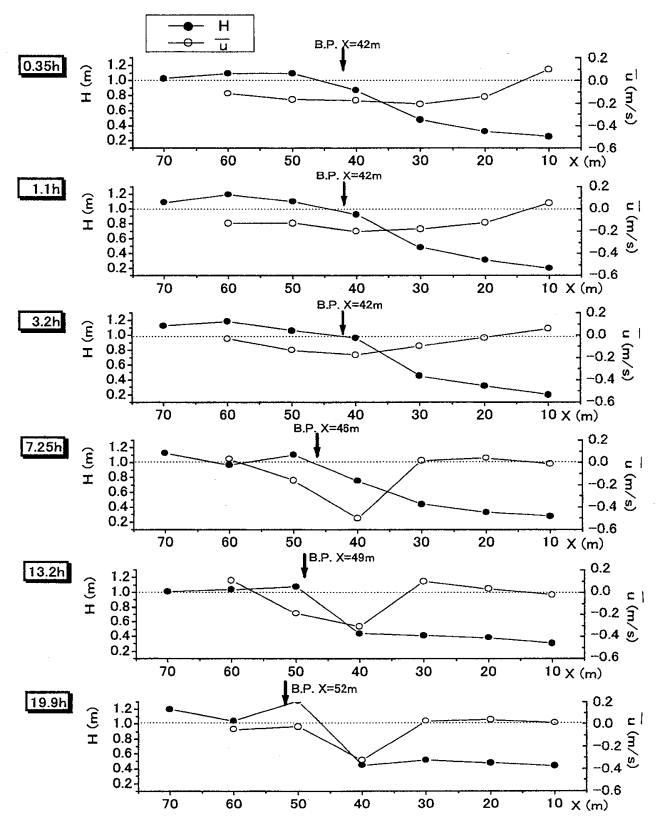

図一7 波高・戻り流れの変化（CASE II：侵食性）

考えられる．ちなみに沖側入反射波分離用の波高計デー 夕から求めたバー発達時の反射率は約 $21 \%$ あったた。

\section{(3) 粒径別漂砂量}

a）粒径別漂砂量の算定

漂砂量は, 単位時間あたりある断面を通過する砂粒子 の体積で定義される.ある岸沖断面位置 $X$ より岸側に存 在する粗砂および細砂の単位幅あたりの体積 $V_{c}, V_{f}$ は, 


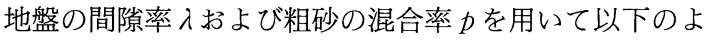
うに表現できる。ただし，いずれも間吵部分を除外した 体積で表示している。

$$
\begin{aligned}
& V_{c}(X, t)=\int_{X_{0}}^{X} \int_{Z_{D}}^{Z_{B}} p(1-\lambda) d Z d X \quad \cdots \cdots \\
& V_{f}(X, t)=\int_{X_{0}}^{X} \int_{Z_{D}}^{Z_{B}}(1-p)(1-\lambda) d Z d X
\end{aligned}
$$

ここで, $Z_{D}(\mathrm{~m})$ は基準面高さ, $Z_{B}(\mathrm{~m})$ は砂表面高さ, $X_{0}$ は岸側の地形変化限界点の座標である.

式 ( 1 ) および ( 2 ) 中で用いる粗砂混合率 $p$ および間吵 率 $\lambda$ の設定については, 混合率 $p$ には図 $-\mathbf{4}$ および図-5 の值を用いればよいが, 間吵率 $\lambda$ は直接求められないた め, 混合率や地形変化から合理的に決定する必要がある.

今, 砂移動の限界水深 (CASE II で $X=80 \mathrm{~m}$ 程度) 以 深の $X=100 \mathrm{~m}$ を越える移動はないとすると, $X=100$ $\mathrm{m}$ ๖岸側の砂粒子体積の総量 $V_{T}\left(=V_{c}(100, t)\right.$ $\left.+V_{f}(100, t)\right)$ は保存されるはずである。図一8 は砂粒子 の総体積 $V_{T}$ の変化を示したものである. 間隙率が CASE I 開始前の初期混合率に対する間隙率 $\left(\lambda_{0}\right)$ から変 化しないとした場合には，図一8中の×印で示すように 砂粒子総体積が $5 \%$ 程度減少した.この原因としては, 地 形測定の誤差, 土砂の混合や地形変化に伴う間隙率の変 化などが考えられる. 砂粒子体積の推定誤差が大きいま までは粒径別漂砂量の推定值が不合理なものとなるた め, 本研究では以下の要因を考慮しできるだけ合理的な 間吵率の設定を行うこととした。

i . 分級の進行による間陌率の変化 $\left(\lambda_{1}\right)$ : 十分締固まっ た状態の試料について, 混合率と間隙率の相関分析 を実施し，両者の関係を表す近似曲線を求め，混合 率によって間隙率が変化することを考慮した。

ii . 新たな堆積域における間隙率の増加 $\left(\lambda_{2}\right)$ : 新たな堆 積域では, 砂が十分に締固まっていないため, 間隙 率が増加する. 間隙率の増加は, メスシリンダーを 用いた実験より，定率で 2 割とした。

iii. 波浪の作用による締固め $\left(\lambda_{3}\right)$ : 波浪圧力の作用およ び漂砂による混合に伴い地盤全体が徐々に締固めら れると考えられるため, $V_{T}$ の推定值が保存されるよ

うに砂層厚に応じて間隙率を定率で減少させた。

粒径別漂砂量の評価には，これらすべての要因を取り 込んだ間隙率を用いた. 図一 8 を見ると, 分級や海浜変形 の進行に伴う間隙率の増加は, 波による締固めによる間 隙率の減少に比べて小さいが, 無視できない量であるこ とがわかる。

粒径別漂砂量 $q_{c}, q_{f}\left(\mathrm{~m}^{2} / s\right)$ （岸向きを正）は次式で表さ れる。

$$
q_{c}(X)=\frac{\partial V_{c}(X, t)}{\partial t}, \quad q_{f}(X)=\frac{\partial V_{f}(X, t)}{\partial t} \ldots \ldots
$$

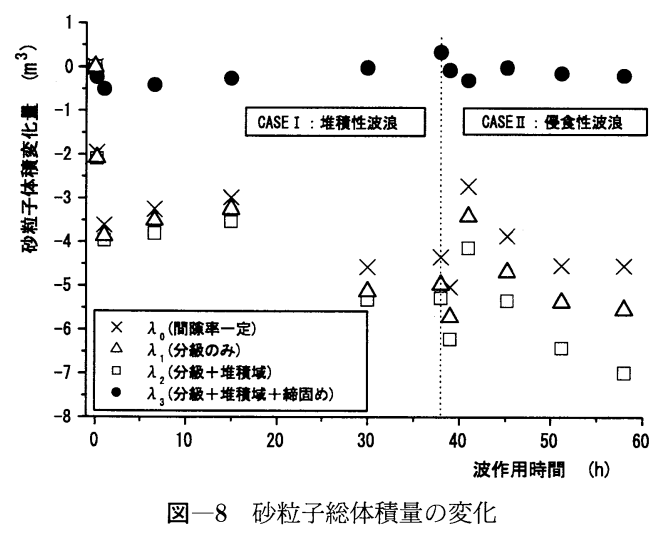

同式による粒径別漂砂量の計算結果を図一 9 12 に示 す. CASE I, CASE II とも波作用開始直後は地形変化が 大きく, 漂砂量がそれ以降と比べて 1 オーダー大きく なった.そこで, 図一9, 10 の $10 \mathrm{~min} \sim 1 \mathrm{~h}$ および図一11, 12 の 0 1 h では $1 / 10$ を乗じた漂砂量值を示してある.

b）粒径別漂砂量に関する考察

粒径別漂砂量の分布（図一9１2）を地形変化・分級の 進行状況（図一，5）と併せて考察する.

まず漂砂帯（漂砂移動の範囲）の幅をみると, CASEI (堆積性), CASEII (侵食性) とも粗砂に比べて細砂の方 がより沖側まで漂砂帯が広がっていることがわかる。ま た粒径別漂砂量の岸沖分布形状は，CASE II では粗砂と 細砂で形状がほぼ一致しているに対して, CASEIでは 形状が大きく異なっている.これは, CASEI では, 粗砂, 細砂それぞれの中央粒径に対する Sunamura and Horikawa (1974) のCパラメ夕は粗砂で 6 程度, 細砂で 13 程 度であり, 粗砂については堆積型, 細砂については中間 型の海浜変形パターンが対応するのに対し, CASE II で はどちらも侵食型となったためと考えられる。

粒径別漂砂量の絶対值について, CASEIでは粗砂と 細砂でほぼ等しい（図一9，10）のに対して，CASE II で は粗砂・細砂の初期構成比 (3:7) にほぼ比例した大き さになっている（図一11，12）。これは，CASE I では掃 流移動が卓越するためアーマリング効果が顕著に現れる のに対し，CASE II では砕波による渦によって砂が巻き 上げられ移動する浮遊砂移動が卓越するためと考えられ る.

さらに地形変化と分級過程および粒径別漂砂量分布を 時間を追って考察する. CASE I では, 当初粗砂, 細砂と もに岸向きに移動し， $X=15 \mathrm{~m}$ 付近にバーが形成され る.その後バーが岸向きに移動し, 汀線付近のバームに 取り込まれる間, 粗砂はなお岸向きに移動するが, $X=$ 10〜30 m における細砂は沖向きに移動する.また表面が 粗砂で覆われた汀線付近では細砂の漂砂量が減少する 


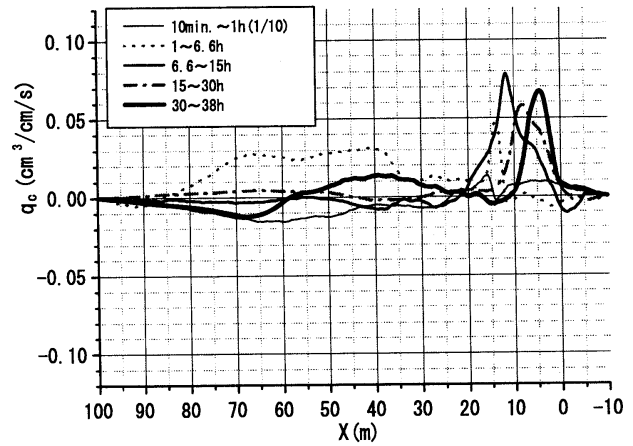

図一9 粗砂漂砂量分布の推移（CASE I ：堆積性）

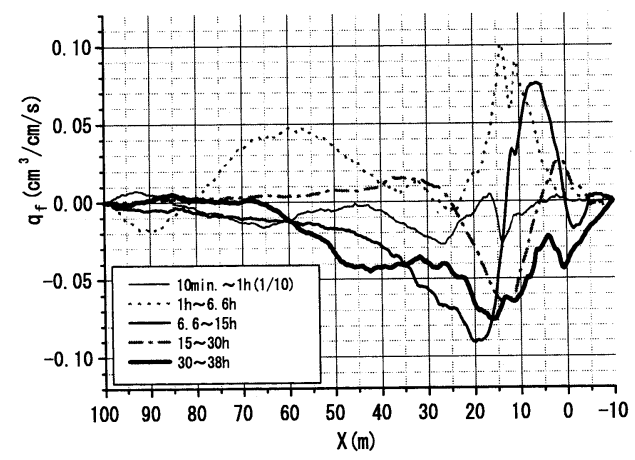

図-10 細砂漂砂量分布の推移（CASE I：堆積性）

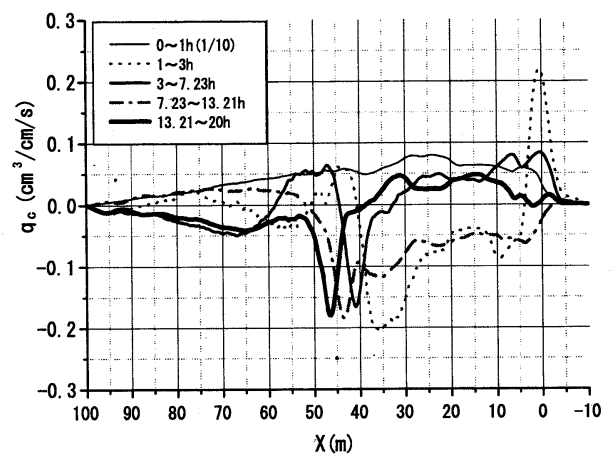

図一11 粗砂漂砂量分布の推移 (CASE II：侵食性)

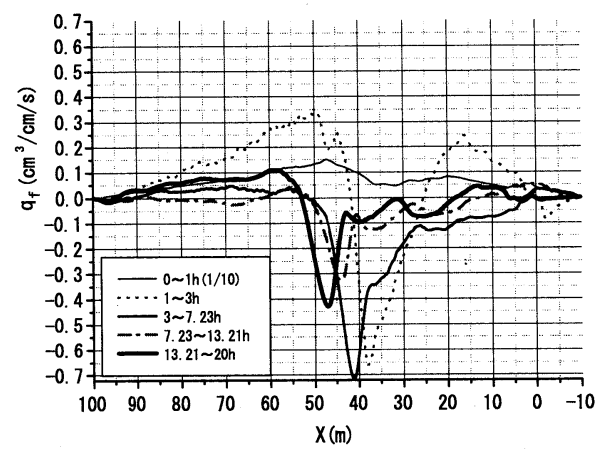

図一12 細砂漂砂量分布の推移（CASE II：侵食性）

して今後は侵食性海浜の回復過程や不規則波条件下の実 験も視野に入れていきたいと考えている.

最後に，今回の実験 (LAMBDA-I) は東京電力(株) と (財)電力中央研究所の共同研究の一環として, 東京大学 と横浜国立大学を含めた 4 者で実施されたものである. 横浜国立大学の岡安章夫助教授, 片山裕之助手, 宇野喜 之氏, 後藤宏志氏ならびに電力中央研究所の森信人氏に は，実験の計画から実施まで絶大なるご支援を頂き，叓 心より感謝いたします，また，計測機器を快くご提供い ただいた東工大，建設省土研，運輸省港研および五洋建 設(株)技研の方々に謝意を表します。

\section{参 考 文 献}

山本幸次・張 達平・佐藤壃司・田中茂信 (1998)：海岸におけ る底質の分級に関する研究, 土木研究所資料, 第 3592 号, pp. 46-58.

清水隆夫 - 池野正明 - 岡安章夫 - 栗山善昭 - 佐藤壃司 - 島田広昭 清水琢三・武若 聡・西隆一郎（1996）：不規則波による大 型海浜断面変形実験と外力場の多点同期計測, 海岸工学論文 集, 第 43 巻, pp. 491-495.

Sunamura, T. and K. Horikawa (1974): Two dimensional shore transformation due to waves, Proc. 14 th Coastal Eng. Conf.,ASCE, pp. 920-938. 